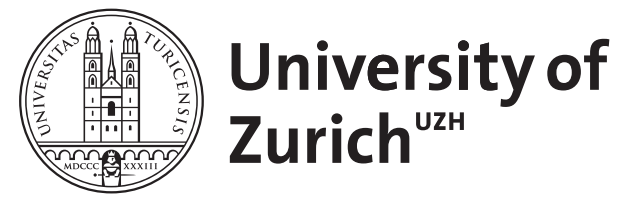

Zurich Open Repository and Archive

University of Zurich

University Library

Strickhofstrasse 39

CH-8057 Zurich

www.zora.uzh.ch

Year: 1986

\title{
Surgery for mitral regurgitation Repair versus valve replacement
}

Krayenbuehl, H P

DOI: https://doi.org/10.1093/oxfordjournals.eurheartj.a062117

Posted at the Zurich Open Repository and Archive, University of Zurich

ZORA URL: https://doi.org/10.5167/uzh-154414

Journal Article

Published Version

Originally published at:

Krayenbuehl, H P (1986). Surgery for mitral regurgitation Repair versus valve replacement. European

Heart Journal, 7(8):638-643.

DOI: https://doi.org/10.1093/oxfordjournals.eurheartj.a062117 


\title{
Surgery for mitral regurgitation Repair versus valve replacement*
}

\author{
H. P. Krayenbuehl \\ Medical Policlinic, Cardiology, University Hospital, CH-809l, Zurich, Switzerland
}

KEY WORDS: Mitral prosthesis; Mitral valve repair; Annuloplasty.

Mitral regurgitation may be treated either by valve repair or valve replacement. Historically, repair with or without prosthetic material was the first method used to restore mitral valve competence. In 1957 Lillehei and co-workers ${ }^{[l]}$ reported on the successful correction of mitral insufficiency by annuloplasty. These early reparative techniques were shown to be quite effective because normalization of huge left atrial v-wave was documented after repair ${ }^{[2]}$. In 1961 Starr and Edwards ${ }^{[3]}$ reported on the first clinically successful implantation of a ball valve prosthesis in the mitral position. Thereafter, cardiac surgeons in the United States preferred the certainty of haemodynamic correction by valve replacement to the possibility of late progression of disease with the reparative procedures. In contrast, European cardiac surgeons under the leadership of Carpentier in France ${ }^{[4.5]}$, Duran in Spain ${ }^{[6]}$ and Yacoub in England[7] continued to use valve repair with steadily improving technique. In recent years, there has been renewed interest in repair in the United States. At the Cleveland Clinic, for instance, the percentage of mitral valve repairs increased from $5 \%$ in 1980 to about $30 \%$ of all mitral valve procedures in $1984^{[8]}$.

This brief overview of the pros and cons of mitral valve repair versus valve replacement in patients with chronic mitral regurgitation is based predominantly on reports which contain data

Submitted for publication on 23 December 1985 and in revised form 7 April 1986

Address for correspondence: H. P. Krayenbuehl, M.D , Medical Poltclinic, Cardiology, University Hospital, CH-8091 Zurich, Switzerland.

*Presented at the Joint Meeting of the Council on Clınical Cardiology, American Heart Association, and the European Society of Cardiology, Washington, 10 November 1985. obtained with both surgical procedures from the same institution. It should, however, be emphasized that even within this selected material there may be some differences in the patient populations treated with the two surgical methods, that the time periods during which the surgical interventions were carried out may not always be strictly the same and the time of follow-up may then vary as well. Moreover there are various types of reparative procedures (annuloplasty with or without ring, valvuloplasty, chordal imbrication, closure of perforation etc.) which are used according to the underlying pathology of the incompetent mitral valve ${ }^{[4.5]}$ and which may give different results in different hands. It is, however, beyond the scope of this short review to analyse in detail the outcome of surgery according to the specific type and extent of mitral valve repair.

\section{Early operative mortality (Table 1)}

When 8 recent studies were averaged, early mortality was $3 \cdot 1 \%$ with repair and $7 \%$ with mitral valve replacement. The higher mortality with mitral valve replacement was particularly striking in the studies of Duran et al. ${ }^{[6]}$ and of Perier et al.$^{[9]}$, whereas Oliveira et al.$^{[10]}$ reported almost the same mortality with both surgical techniques. In the series of the University Hospital in Zurich ${ }^{[1]}$ of patients operated between 1972 and 1982, operative mortality was somewhat higher with repair than with mitral valve replacement although the difference was not statistically significant. As far as preoperative symptomatic status (NYHA class) and age are concerned, five studies ${ }^{[6.79 .10 .12]}$ reported similar data in the groups with mitral valve replacement and repair (Table 1). In two studies ${ }^{[1,13]}$, patients undergoing repair were younger than those who had mitral valve replacement; operative mortality, however did not differ. 
Tablel Early (operative) mortality in mitral regurgitation

\begin{tabular}{|c|c|c|c|c|c|c|c|}
\hline \multirow{2}{*}{ Author } & \multirow{2}{*}{ Year } & \multicolumn{3}{|c|}{ MVR } & \multicolumn{3}{|c|}{ Repair } \\
\hline & & $\begin{array}{c}\text { Mortality } \\
(\%)\end{array}$ & NYHA & A & $\begin{array}{c}\text { Mortality } \\
(\%)\end{array}$ & NYHA & $\mathbf{A}$ \\
\hline Duran (6) & 1980 & $11 \cdot 4$ & $3 \cdot 1$ & $43 \cdot 3$ & 1.8 & mean $2 \cdot 7$ & $41 \cdot 4$ \\
\hline Yacoub (7) & 1981 & $7 \cdot 0$ & $\begin{array}{c}87 \% \\
\text { III/IV }\end{array}$ & $55 \cdot 3$ & $3 \cdot 1$ & $\begin{array}{r}83 \% \\
\text { III/IV }\end{array}$ & 53.8 \\
\hline Oliveira (10) & 1983 & $5 \cdot 0$ & $\begin{array}{c}56 \% \\
\text { III/IV }\end{array}$ & 56 & 4.9 & $\begin{array}{c}51 \% \\
\text { III/IV }\end{array}$ & 59 \\
\hline Pener (9) & 1984 & $\begin{array}{l}12.0(\mathrm{BP}) \\
13.0(\mathrm{SE}) \\
12.0(\mathrm{BS})\end{array}$ & $\begin{array}{l}2 \cdot 5 \\
2 \cdot 5 \\
2 \cdot 4\end{array}$ & $\begin{array}{l}49 \cdot 6 \\
51 \cdot 8 \\
51 \cdot 4\end{array}$ & $2 \cdot 0$ & mean $2 \cdot 4$ & $47 \cdot 1$ \\
\hline Adebo (12) & 1984 & $6 \cdot 8$ & $\begin{array}{c}73 \% \\
\text { III/IV }\end{array}$ & 62 & 0 & $\begin{array}{c}81 \% \\
\text { III/IV }\end{array}$ & 62 \\
\hline Orszulak (13) & 1985 & $7 \cdot 5$ & & 64 & $6 \cdot 1$ & $\begin{array}{l}79 \% \\
\text { III/IV }\end{array}$ & 57 \\
\hline Cosgrove (8) & 1985 & $4 \cdot 6$ & & & $2 \cdot 3$ & & \\
\hline Schmidli (11) & 1985 & 1.6 & $2 \cdot 8$ & $55 \cdot 5$ & $4 \cdot 8$ & mean $2 \cdot 8$ & $42 \cdot 4$ \\
\hline Mean & & 7.0 & & & $3 \cdot 1$ & & \\
\hline
\end{tabular}

$\mathrm{BP}=$ bioprosthesis, $\mathrm{BS}=\mathrm{Björk}-$ Shiley prosthesis, $\mathrm{MVR}=$ mitral valve replacement, $\mathrm{SE}=\mathrm{Starr}-\mathrm{Edwards}$ prosthesis, NYHA $=$ functional class according to the New York Heart Association, $A=$ mean age in years.

\section{Survival after surgery (Table 2 )}

In all 7 studies from which survival data following both mitral valve replacement and repair were available, 5-year survival was clearly better after repair than after mitral valve replacement $(89$ versus $74 \%$ ). The higher survival with repair is not only due to a lower operative mortality with this procedure, because in the two studies of Oliveira et al..$^{[10]}$ and Schmidli et al. ${ }^{[11]}$ which showed no difference in early mortality, 5-year survival with repair exceeded that after valve replacement. This better survival after repair irrespective of early mortality is essentially related to less thromboembolism and better postoperative left ventricular function with repair than with mitral valve replacement.

\section{Thromboembolism after surgery (Table 3)}

The rate of thromboembolism averaged $0.9 \%$ per year with repair and $4.1 \%$ per year with mitral valve replacement. The difference in the rate of thromboembolism was especially marked when repair was compared with valve replacement with Starr-Edwards or Björk-Shiley prostheses ${ }^{[9]}$. When bioprostheses were used for mitral valve replacement as in the studies of Duran et al. ${ }^{[6]}$ and Perier $e t$
Table 2 5-year survival after surgery for mitral regurgitation

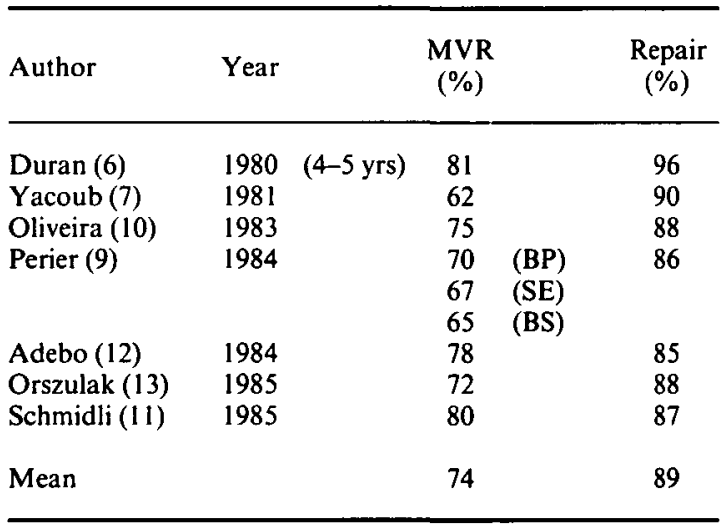

$\mathbf{B P}=$ bioprosthesis, $\mathbf{B S}=\mathrm{Björk}-$ Shiley prosthesis, $\mathrm{MVR}=$ mitral valve replacement, $S E=S t a r r-E d w a r d s$ prosthesis.

$a l^{[9]}$, the difference in thromboembolism with respect to repair was less evident.

Inspection of Table 3 reveals that especially after mitral valve replacement there were large differences in the rate of thromboembolism between the various studies. Undoubtedly, they are related to 
the definition of thromboembolism used by the different authors. For instance, in one study ${ }^{[10]}$ a thromboembolism was defined as a sudden new postoperative neurological disturbance resulting in a permanent deficit, whereas Duran et al.$^{[6]}$ counted as thromboembolism any suspicious postoperative event reported by the patient, relatives or family physician. These interauthor differences in definition of thromboembolism should, however, not invalidate the comparison of the rate of thromboembolism after repair and mitral valve replacement from the data given in Table 3 because only paired observations of the various centres were included. Haemorrhagic complications after repair are few because only a minority of patients are maintained

Table 3 Thromboembolism after surgery for mitral regurgitation

\begin{tabular}{|c|c|c|c|}
\hline Author & Year & $\begin{array}{c}\text { MVR } \\
\text { (\% per year) }\end{array}$ & $\begin{array}{c}\text { Repair } \\
\text { (\% per year) }\end{array}$ \\
\hline Duran (6) & 1980 & $4 \cdot 1$ & $2 \cdot 4$ \\
\hline Oliveira (10) & 1983 & $1 \cdot 4$ & 0.2 \\
\hline Perier (9) & 1984 & $\begin{array}{ll}1.9 & (\mathrm{BP}) \\
5.0 & (\mathrm{SE}) \\
5.8 & (\mathrm{BS})\end{array}$ & $0 \cdot 3$ \\
\hline Adebo (12) & 1984 & $4 \cdot 8$ & 0 \\
\hline Orszulak (13) & 1985 & $8 \cdot 0$ & 1.8 \\
\hline Schmidli (11) & 1985 & $2 \cdot 1$ & 0.7 \\
\hline Mean & & $4 \cdot 1$ & 0.9 \\
\hline
\end{tabular}

$\mathrm{BP}=$ bioprosthesis, $\mathrm{BS}=\mathrm{Björk}-$ Shiley prosthesis, $\mathrm{MVR}=$ mitral valve replacement, $\mathrm{SE}=\mathrm{Star}-\mathrm{Edwards}$ prosthesis. on long-term anticoagulation. Persistent atrial fibrillation is considered an indication for longterm anticoagulation by some authors ${ }^{[14]}$ whereas others $^{[7]}$ discontinue oral anticoagulants in all patients 6 weeks after surgery.

\section{Postoperative left ventricular function (Table 4)}

Echocardiography ${ }^{[15]}$, radionuclide techniques ${ }^{[16-18]}$ and cineventriculography ${ }^{[6,14,19-21]}$ have been used to determine left ventricular ejection fraction before and after surgery. Early postoperative measurements within one month after surgery were performed by Boucher et al. ${ }^{[18]}$, David et al. ${ }^{[20]}$ and Bonchek et al. ${ }^{[21]}$. The other studies in Table 4 were performed between 3 and 30 months after surgery. When these admittedly heterogeneous data were pooled (Table 4) no change in ejection fraction was observed after repair, whereas after mitral valve replacement there was a decrease in all studies except that of Peter et al. ${ }^{[17]}$. In our own material (Figure 1) echocardiographically determined left ventricular transverse diameter shortening decreased significantly after mitral valve replacement but remained essentially unchanged following valve reconstruction. Of particular interest is the study of David et al. ${ }^{[20]}$ because, in addition to a group with conventional valve replacement and a group with valvuloplasty, a third group of patients was reported, who underwent mitral valve replacement whereby the anterior leaflet was partially excised but its chordae and the entire posterior leaflet and its chordae were left attached to the papillary muscles. In this particular group with mitral valve replacement ejection

Table 4 LV ejection fraction before and after surgery for mitral regurgitation

\begin{tabular}{|c|c|c|c|c|c|c|c|c|}
\hline \multirow[b]{2}{*}{ Author } & \multirow[b]{2}{*}{ Year } & \multirow[b]{2}{*}{ Method } & \multicolumn{3}{|c|}{ MVR } & \multicolumn{3}{|c|}{ Repair } \\
\hline & & & $\begin{array}{l}\text { pre } \\
(\%)\end{array}$ & & $\begin{array}{l}\text { post } \\
(\%)\end{array}$ & $\begin{array}{l}\text { pre } \\
(\%)\end{array}$ & & $\begin{array}{l}\text { post } \\
(\%)\end{array}$ \\
\hline Schuler (15) & 1979 & Echo & 66 & & 47 & 70 & & 65 \\
\hline Duran (6) & 1980 & Angio & 54 & & 47 & 47 & & 54 \\
\hline Lessana (14) & 1981 & Angio & & & & 58 & & 52 \\
\hline Phillips (16) & 1981 & Radionuclide & 62 & & 50 & & & \\
\hline Peter (17) & 1981 & Radionuclide & 56 & & 54 & & & \\
\hline Boucher (18) & 1981 & Radionuclide & 66 & & 48 & & & \\
\hline Huikuri (19) & 1983 & Angio & 58 & & 50 & & & \\
\hline David (20) & 1983 & Angio & 62 & & 51 & 63 & & 68 \\
\hline Bonchek (21) & 1984 & Angio & & & & 66 & & 62 \\
\hline Mean & & & 61 & $\rightarrow$ & 50 & 61 & $\rightarrow$ & 60 \\
\hline
\end{tabular}



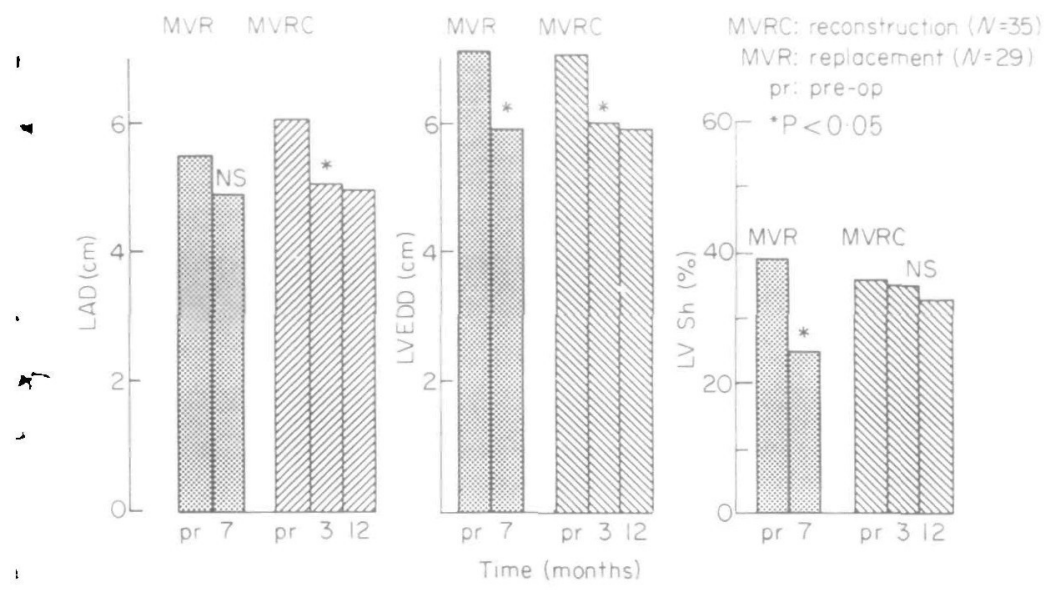

Figure 1 Echocardiographic assessment of left heart size and function before and after surgery for chronic mitral regurgitation. Prior to surgery left atrial (LAD) and left ventricular end-diastolic (LVEDD) diameter was increased to a similar extent in both the group with mitral valve replacement and mitral valve reconstruction. Similarly there was no difference in left ventricular transverse diameter systolic shortening (LV Sh,\%) before surgery. Postoperatively, LVEDD and LAD decreased in both groups. Left ventricular transverse diameter shortening remained within the normal range after reconstruction whereas after valve replacement it decreased significantly. Hence, left ventricular ejection performance is preserved after repair but not after valve replacement. (Courtesy by Prof. $\mathbf{M}$. Rothlin, Clinic for Cardiovascular Surgery, University Hospital, Zürich).

Table $5 \quad L V$ end-diastolic volume index before and after surgery for mitral regurgitation

\begin{tabular}{|c|c|c|c|c|c|c|c|c|}
\hline \multirow[b]{2}{*}{ Author } & \multirow[b]{2}{*}{ Year } & \multirow[b]{2}{*}{ Method } & \multicolumn{3}{|c|}{ MVR } & \multicolumn{3}{|c|}{ Repair } \\
\hline & & & $\begin{array}{c}\text { pre } \\
\left(\mathrm{ml} / \mathrm{m}^{2}\right)\end{array}$ & & $\underset{\left(\mathrm{ml} / \mathrm{m}^{2}\right)}{\text { post }}$ & $\begin{array}{c}\text { pre } \\
\left(\mathrm{ml} / \mathrm{m}^{2}\right)\end{array}$ & & $\begin{array}{c}\text { post } \\
\left(\mathrm{ml} / \mathrm{m}^{2}\right)\end{array}$ \\
\hline Lessana (14) & 1981 & Angio & & & & 148 & & 89 \\
\hline Boucher (18) & 1981 & Radionuclide & 131 & & 78 & & & \\
\hline Huikuri (19) & 1983 & Angio & 138 & & 100 & & & \\
\hline David (20) & 1983 & Angio & 108 & & 101 & 123 & & 96 \\
\hline Bonchek (2I) & 1984 & Angio & & & & 143 & & 84 \\
\hline Mean & & & 126 & $\rightarrow$ & 93 & 138 & $\rightarrow$ & 90 \\
\hline
\end{tabular}

fraction remained unchanged after surgery in contrast to the group with conventional mitral valve replacement in which ejection fraction decreased. In the group with valvuloplasty, ejection fraction did not change. Hence, it is evident that the continuity between mitral annulus and left ventricular wall through the leaflets, chordae tendineae and papillary muscles plays a major role in the preservation of left ventricular function after correction of chronic mitral regurgitation. The less favourable postoperative left ventricular function after conventional mitral valve replacement appears to be due to a loss of long-axis shortening and distention or disruption of the basilar musculature.

With respect to the postoperative changes of left ventricular end-diastolic volume index (Table 5), the pooled data do not show a major difference between repair and mitral valve replacement. With both surgical methods end-diastolic volume index decreased although in the study of David et al. ${ }^{[20]}$ the decrease was significant only after repair but not after mitral valve replacement.

Left ventricular filling dynamics as assessed by the echocardiographic peak velocity of transverse 
diameter lengthening was found by St John Sutton et al. ${ }^{[22]}$ to be close to normal after valve repair whereas this quantity was depressed following mitral valve replacement by mechanical as well as by Hancock prostheses.

\section{Reoperations after surgery for mitral regurgitation (Table 6)}

To make the analysis as complete as possible, some recent studies were included from institutions in which reoperations solely after repair ${ }^{[10,13,23,24]}$ or after mitral valve replacement ${ }^{[25]}$ were reported. When all these data are pooled it is apparent that reoperations after repair $(2.2 \%$ per year) are twice as frequent as they are after mitral valve replacement ( $1.1 \%$ per year). It should, however, be noted that the excellent study of Perier et al..$^{[9]}$ which included 3 groups with mitral valve replacement and one group with repair, followed during the same time-period at the same institution, showed no significant difference in the rate of reoperation after repair and mitral valve replacement.

The incidence of infective endocarditis appears to be less after repair than after mitral valve replacement. In Duran's ${ }^{[6]}$ series, infective endocarditis occurred at a rate of $0.4 \%$ per year after repair and of $2.2 \%$ per year after mitral valve replacement. Follow-up observations from our hospital[1]

\section{Table 6 Reoperations after surgery for mitral regurgitation}

\begin{tabular}{|c|c|c|c|}
\hline Author & Year & $\begin{array}{c}\text { MVR } \\
\text { (\% per year) }\end{array}$ & $\begin{array}{c}\text { Repair } \\
\text { (\% per year) }\end{array}$ \\
\hline Duran (6) & 1980 & 0.9 (BP) & 1.6 \\
\hline Yacoub (7) & 1981 & $1 \cdot 3$ (Homogr.) & 0.9 \\
\hline Oliveira (10) & 1983 & - & 1.7 \\
\hline Perier (9) & 1984 & $\begin{array}{ll}2 \cdot 4 & \text { (BP) } \\
0 \cdot 9 & \text { (SE) } \\
2 \cdot 3 & \text { (BS) }\end{array}$ & 1.6 \\
\hline Adebo (12) & 1984 & $\begin{array}{ll}0 & (59 \% \text { BP } \\
& 41 \% \mathrm{MP})\end{array}$ & $1 \cdot 2$ \\
\hline Nunley (23) & 1984 & - & $4 \cdot 5$ \\
\hline Orszulak (13) & 1985 & - & $2 \cdot 8$ \\
\hline Schmidli (11) & 1985 & $\begin{array}{cl}1.5 & (47 \% \text { BP } \\
& 53 \% \mathrm{MP})\end{array}$ & $2 \cdot 3$ \\
\hline Penkoske (24) & 1985 & - & $3 \cdot 5$ \\
\hline Mitchell (25) & 1985 & $\begin{array}{ll}0.8 & (\mathrm{SE}) \\
1.0 & (\mathrm{BP})\end{array}$ & - \\
\hline Mean & & $1 \cdot 1 \quad(6$ studies) & $2 \cdot 2 \quad(9$ studies $)$ \\
\hline
\end{tabular}

Legends: Homogr $=$ fresh aortic homograft, $\mathrm{MP}=$ mechanical prosthesis, other abbreviations as in Table 1 . revealed no infective endocarditis in 42 patients with mitral valve reconstruction whereas it occurred in 3 out of 122 patients after mitral valve replacement $(0.8 \%$ per year). Similar results have been reported by others ${ }^{[7,10]}$.

In summarizing the pros and cons of the use of repair or valve replacement in the surgical treatment of mitral regurgitation the following points merit emphasis:

(1) Operative mortality with repair is about half that with valve replacement.

(2) Long-term survival with repair is superior to that after valve replacement.

(3) Thromboembolism is about 4 times less frequent after repair than after valve replacement. The most striking differences have been reported when mechanical valves were compared with repair. (4) Postoperative left ventricular systolic and filling dynamics are preserved following repair, but are reduced after conventional valve replacement.

(5) Reoperations after repair are on the average twice as frequent as after mitral valve replacement, although this trend was not evident in all studies.

(6) Postoperative infective endocarditis seems to be less frequent after repair than after valve replacement.

Indications and contraindications for mitral valve repair

From all the foregoing it would appear that repair is superior to mitral valve replacement. The ideal case for repair is a young patient with severe mitral regurgitation the aetiology being rheumatic or myxomatous degeneration. Chronic atrial fibrillation should not be present, left ventricular systolic ejection fraction should be within the normal range and short-term follow-up should show a progression of heart size. At surgical inspection, valve tissue should be preserved.

Not all types of mitral regurgitation are, however, amenable to reconstruction. Extensive leaflet destruction from rheumatic fever or infective endocarditis cannot be repaired. Other heretofore established contraindications such as marked alterations of the subvalvular apparatus and multiple rupture of chordae to the anterior mitral leaflet are becoming more and more relative. In a recent study ${ }^{(26)}$, it was estimated that reparative techniques can be effectively used in more than $90 \%$ of patients operated upon with mitral regurgitation. Conservative mitral surgery may even be performed in an emergency situation such as in acute ischaemic mitral 
regurgitation. Valve replacement in mitral regurgitation due to coronary artery disease carries a grave prognosis, the perioperative mortality ranging between 18 and $20 \%{ }^{[27,28]}$. With valve repair such high risk patients appear to fare considerably better, Kay et al. ${ }^{[29]}$ having reported a hospital mortality as low as $6 \%$. Finally a rare but very good indication for valve repair is mitral valve perforation due to aortic valve endocarditis.

In conclusion, valve repair for mitral regurgitation is becoming increasingly popular. It should, however, be emphasized that because valve repair operations are inherently not stereotyped and are often of an improvisational nature, the artistic skill of the individual cardiac surgeon is and will remain the key factor for the ultimate result of repair.

\section{References}

[1] Lillehei CW, Gott VL, deWall RA, Varco RL. Surgical correction of pure mitral insufficiency by annuloplasty under direct vision. J Lancet 1957; 77: 446-9.

[2] McGoon DC. Repair of mitral insufficiency due to ruptured chordae tendineae. J Thorac Cardiovasc Surg $1960 ; 39: 357-62$.

[3] Starr A, Edwards ML. Mitral replacement: Clinical experience with a ball-valve prosthesis. Ann Surg 1961; 154: 726-40.

[4] Carpentier A, Relland J, Deloche A et al. Conservative management of the prolapsed mitral valve. Ann Thorac Surg 1978; 26: 294-300.

[5] Carpentier A, Chauvaud S, Fabiani JN et al. Reconstructive surgery of mitral valve incompetence. Tenyear appraisal. J Thorac Cardiovasc Surg 1980; 79 : $338-48$.

[6] Duran CG, Pomar JL, Revuelta JM et al. Conservative operation for mitral insufficiency. Critical analysis supported by postoperative hemodynamic studies in 72 patients. J Thorac Cardiovasc Surg 1980; 79: 326-37.

[7] Yacoub M, Halim M, Radley-Smith R, McKay R, Nijveld A, Towers $M$. Surgical treatment of mitral regurgitation caused by floppy valves: Repair versus replacement. Circulation 1981; 64 (Suppl II): 210-6.

[8] Cosgrove DM. Mitral valve reconstruction. Cardiology Clinics 1985; 3: 461-9.

[9] Perier P, Deloche A, Chauvaud S et al. Comparative evaluation of mitral valve repair and replacement with Starr, Björk, and porcine valve prostheses. Circulation 1984; 70 (Suppl I): 187-92.

[10] Oliveira DBG, Dawkins KD, Kay PH, Paneth M. Chordal rupture II: Comparison between repair and replacement. Br Heart J 1983; 50: 318-24.

[11] Schmidli J, Rothlin ME, Turina M, Senning A. Langzeitresultate nach Mitralklappenoperation wegen Mitralinsuffizienz 1972-1982. Schweiz med Wochenschr 1985; 115: 430-9.

[12] Adebo OA, Ross JK. Surgical treatment of ruptured mitral valve chordae. A comparison between valve replacement and valve repair. Thorac Cardiovasc Surgeon 1984; 32: 139-42.
[13] Orszulak TA, Schaff HV, Danielson GK et al. Mitral regurgitation due to ruptured chordae tendineae. $J$ Thorac Cardiovasc Surg 1985; 89: 491-8.

[14] Lessana A, Herreman F, Boffety C et al. Hemodynamic and cineangiographic study before and after mitral valvuloplasty (Carpentier's technique). Circulation 1981; 64 (Suppl II): 195-202.

[15] Schuler G, Peterson KL, Johnson A et al. Temporal response of left ventricular performance to mitral valve surgery. Circulation 1979; 59: 1218-31.

[16] Phillips HR, Levine FH, Carter JE et al. Mitral valve replacement for isolated mitral regurgitation: Analysis of clinical course and late postoperative left ventricular ejection fraction. Am J Cardiol 1981; 48: 647-54.

[17] Peter CA, Austın EH, Jones RH. Effect of valve replacement for chronic mitral insufficiency on left ventricular function during rest and exercise. $\mathrm{J}$ Thorac Cardiovasc Surg 1981; 82: 127-35.

[18] Boucher CA, Bingham JB, Osbakken MD et al. Early changes in left ventricular size and function after correction of left ventricular volume overload. Am J Cardiol 1981; 47: 991-1004.

[19] Huikuri HV. Effect of mitral valve replacement on left ventricular function in mitral regurgitation. Br Heart $\mathbf{J}$ 1983; 49: 328-33.

[20] David TE, Uden DE, Strauss HD. The importance of the mitral apparatus in left ventricular function after correction of mitral regurgitation. Circulation 1983; 68 (Suppl II); 76-82.

[21] Bonchek LI, Olinger GN, Siegel R, Tresch DD, Keelan $\mathrm{MH} \mathrm{J}$. Left ventricular performance after mitral reconstruction for mitral regurgitation. J Thorac Cardiovasc Surg 1984; 88: 122-7.

[22] St John Sutton MG, Traill TA, Ghafour AS, Brown DJ, Gibson DG. Echocardiographic assessment of left ventricular filling after mitral valve surgery. Br Heart $\mathbf{J}$ 1977; 39: 1283-91.

[23] Nunley DL, Starr A. The evolution of reparative techniques for the mitral valve. Ann Thorac Surg 1984; 37: 393-7.

[24] Penkoske PA, Ellis FH Jr, Alexander S, Watkins E Jr. Results of valve reconstruction for mitral regurgitation secondary to mitral valve prolapse. Am J Cardiol 1985; 55: 735-8.

[25] Mitchell RS, Miller DC, Stinson EB et al. Perspectives on the porcine xenograft valve. Cardiology Clinics 1985; 3: 371-84.

[26] Spencer FC, Colvin SB, Culliford AT, Isom OW. Experiences with the Carpentier techniques of mitral reconstruction in 103 patients $(1980-1985)$. J Thorac Cardiovasc Surg 1985; 90: 341-50.

[27] DiSesa VJ, Cohn LH, Collins JJ, Koster JK, Van Devanter S. Determinants of operative survival following combined mitral valve replacement and coronary revascularization. Ann Thorac Surg 1982; 34: 482-8.

[28] Czer LSC, Gray RJ, de Robertis MA et al. Mitral valve replacement: Impact of coronary artery disease and determinants of prognosis after revascularization. Circulation 1984; 70 (Suppl I): 198-207.

[29] Kay JH, Zubiate P, Mendez MA, Vanstrom N, Yokoyama T, Gharavi MA. Surgical treatment of mitral insufficiency secondary to coronary artery disease. J Thorac Cardiovasc Surg 1980; 79: 12-8. 